\title{
Effect of Advertisement in Consumer Behavior
}

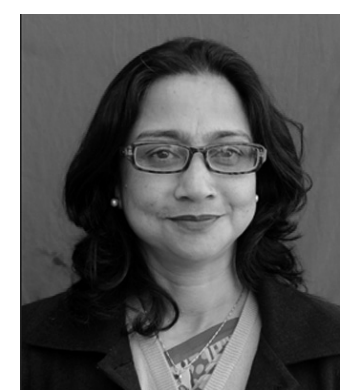

Binita Manandhar, MPhil*

\begin{abstract}
This study is intended to analyze the impact of advertisement in consumer behavior. The purpose of this paper is to examine the impact of advertisement in consumer behavior. Convenience sampling is used for the study. All together 250 questionnaires were distributed to the customers from Kathmandu City and only 200 questionnaires were received. Most of the respondents have taken advertising as promotional tools that can convince the customers towards the products the study shows that the customers are highly affected by the advertisement as it creates curiosity on the customers and it provides information of the products, which is also important for the customers before buying any goods and services. So there is a positive impact of advertisement on consumer behavior. According to the respondents, television is more effective media to influence and convince the audience towards the advertised products.
\end{abstract}

Key Words: Consumer Behavior, Advertisement.

\section{Background}

The term consumer behavior is defined as the behavior consumers exhibit in searching for, purchasing for, using, evaluating and disposing products and services that they expect will satisfy their needs. Consumer behavior focuses on how individuals make decisions to spend their available resources such as time, effort, money, on consumptions related items. That includes what they buy, when they buy, why they buy, where they buy, how often they buy, how often they use, how they evaluate after the purchase and use it and impact of evaluations on future purchase and how they dispose it (Schiffman \& Kanuk, 2009).

Consumer behavior is defined as the decision process and physical activity individuals engage in when evaluating, acquiring, using or disposing of goods and services (Louden \& Bitta, 2002).

Consumer behavior is the study of the processes involved when individuals or groups select, purchase, use or dispose of products, services, ideas or experiences to satisfy needs and desires. Consumer behavior is new issue and a controversy subject and challenging that includes individuals and what they buy, why and how to purchase them, marketing and marketing mix of marketing (Brosekhan \& Velayutham, 2013). In globalizing world

* Lecturer, Shanker Dev Campus, Tribhuvan University, Nepal 
where economic crisis deepen and competition gets fiercer, consumers are becoming more and more important. Every individual is a consumer. There are rapid changes in demands and desires of the consumers who are considered to be center of the modern marketing. Companies need to increase the rate of their research and development activities in order to be able to learn these changes and improvements relating to fulfill the demands and need of consumers. Consumer satisfaction, which is widely accepted by developed countries and gaining importance day by day, can be achieved by perceiving the consumers and consumer behavior (Yakup \& Jablonsk, 2012).

Consumer behavior is physical activity; mental and emotional people do when select, purchase, use and dispose of goods and services to satisfy their needs. Consumer behavior is described as series of activities directly toward the acquisition use and disposal of goods and services occurs. These activities include the decisions that are made before and after the procedure (Haghshenas, Abedi, Ghorbani, Kamali, \& Mohammadnaser, 2012).

The principal aim of consumer behavior analysis is to explain why consumers act in particular ways under certain circumstance; it tries to determine the factors that influence consumer behavior, especially the economic, social and psychological aspects (Ayanwale, Alimi, \& Ayanbimipe, 2005).

In view of the importance and scope of its application to determine the marketing strategies, the focus is to identify the factors influencing consumer behavior that will help to identify the market and its behavior particularly in the area of consumer goods.

Advertising is a way of communication to convince an audience for taking purchase decision about a product or service and delivering information to viewers (Niazi, Siddqui, Shah, \& Hunjra, 2012). Advertising is a non-personal paid form where ideas, concepts, products or services, and information are promoted through media by an identified sponsor to persuade or influence behavior (Alimi \& Ayanbimipe, 2005; Ayanwale, 2000).

Advertising is taken as one of the renowned marketing weapons for its long lasting impact on viewer's mind as its exposure is much broader (Katke, 2007).

As a promotional strategy, advertising serve as a major tool in creating product awareness in the mind of a potential consumer to take eventual purchase decision. Advertising through all mediums influence audiences, but television is one of the strongest medium of advertising and due to its mass reach, it can influence not only individual's attitude, behavior, life style , exposure and in the long run, even the culture of the country (Latif \& Abideen, 2011).

When consumer watches an advertisement about the brand and develops likeness for the brand and then eventually willing to purchase it. The major advertising is to create positive attitude towards the advertisement and the brand until consumer purchases the product and 
through this positive attitude create emotional responses in the mind of consumer (Goldsmith \& Lafferty, 2002).

According to traditional hierarchy of effects models, advertising affect of advertising exposure leads to brand cognition and cognition about the advertisement, which then leads to the attitude towards the advertisement and the brand until their purchase intent (Mendelson \& Bolls, 2002).

\section{Statement of the Problem}

Consumer behavior is the study of how individuals, groups and organizations select, buy, use and dispose of goods, services, ideas or experiences to satisfy their needs and wants.

The study of consumer behavior is very important for the marketers as it enables them to understand and predict buying behavior of consumers in the market. It is concerned with what they buy, why they buy, when and where they buy and how often they buy and how do they consume and dispose them after using them. Consumer research is the methodology used to study consumer behavior that takes place at every phase of the consumption process such as before the purchase, during the purchase and after the purchase. Research shows that two different buyers buying the same product for different reasons, paid different prices, used in different ways, have different emotional attachments towards the things (Brosekhan \& Velayutham, 2013).

In a today's dynamic and highly competitive business environment customers are becoming more demanding and their expectations are continuously rising while marketers are continuing their efforts to meet them (Alsmadi, 2006).

Consumer behavior is influenced by the buyer characteristics and by the buyer's decision process. The buyers' decision process is influenced by various factors. Marketers need to understand the factors influencing consumer buying decisions to develop marketing strategies. People buy goods and services for personal consumption. Consumers are vary tremendously by different factors and the marketers need to identify those factors influencing purchasing decisions as it is difficult for them to predict consumer behavior.

There has been limited research in marketing in Nepalese context and it is rarer in the case of consumer behavior. It is also evident in the field of academic research. Very few academic research studies conducted in the field of marketing and consumer behavior. This study is particularly important in Nepalese context where the marketers have been facing marketing problems due to inadequate accessibility to market. The marketers also have been facing the problems in identifying the factors that can influence the purchasing decisions of the buyers. The Nepalese business houses can generate many ideas in the field of marketing through this type of research. This kind of research will be helpful for the marketers for the understanding consumer properly. This study will explain the rationale behind consumers 
and their buying decisions. It also will help the marketers to understand why consumers act as they do, and will seek to examine the factors influencing the consumers to purchase consumer goods. Hence the basic research issue being propositioned is what factors influence consumer buying behavior in respect to consumer goods.

The study starts with the following questions:

- What are the factors influencing consumer buying decisions?

- Does advertisement have impact on consumers' buying decisions?

- Which advertising media is most effective to convince the consumers?

\section{Objectives of the study}

The objectives of the study are as follows:

- To analyze the consumer buying behavior

- To examine the effect of advertisement in consumer buying decisions

\section{Limitations of the study}

The study has following limitations:

- This study analyses only the effect of advertisement in consumer buying decisions

- The respondents for the study is taken only from Kathmandu City

- Convenience sampling is done for the study

\section{Review of Literature}

Priya, Baisya and Sharma (2010) analyzed the impact of children's attitudes towards television advertisement on their buying behavior. The study found that the children's attitudes towards advertisement influence the demand for the advertised product. The study also explained about the cognitive changes among the different groups of the children that lead to forming different attitudes towards the advertisement.

Wang, sun, lei and Toncar (2009) examined the beliefs and attitudes towards online advertising among Chinese consumers. The research identified five belief factors such as entertainment, information seeking, credibility, economy and value corruption that under lie Chinese consumer's attitudes towards online advertising. The study found that Attitudes Towards Online Advertising (ATOA) is a significant positive predictor for clicking advertisement and online shopping frequency. 


\section{Research Methodology}

\section{Research Design}

The research design of this study is descriptive as well as analytical method. Descriptive research design describes the way of overcoming the facts, problems and analytical research design presents the facts, figures and problems and investigates into reasons and recommends solutions for further improvement.

\section{Nature and Sources of Data}

Necessary data and information were collected through primary sources to obtain the objectives of the research. The data was collected through questionnaire. Comprehensive literature reviews was made to analyze the impact of advertisement in consumer behavior.

\section{Population and Sample}

This study is intended to analyze the impact of advertisement in consumer behavior. Convenience sampling is used for the study. Total sample are classified on the basis of different characteristics of the respondents. The respondents were requested to fill the structured self administered questionnaires randomly. All together 250 questionnaires were distributed to the customers from Kathmandu valley and only 200 questionnaires were received.

Table 1: General Profile of the Respondents

\begin{tabular}{|l|l|l|l|l|l|l|l|}
\hline Gender & No & Age & No & Position & No & Education & No \\
\hline Male & 100 & Below 30 & 40 & consumer & 100 & Illiterate & 25 \\
\hline Female & 100 & 31 to 50 & 130 & Producer/Seller & 50 & Up to +2 & 25 \\
\hline Total & 200 & 51 above & 30 & Media/Advertiser & 50 & Bachelor & 70 \\
\hline & & Total & 200 & & 200 & $\begin{array}{l}\text { A b o v e } \\
\text { Bachelor }\end{array}$ & 80 \\
\hline & & & & & & Total & 200 \\
\hline
\end{tabular}

Source: Field Survey

Table 1 show that 50 percent respondents are male and 50 percent are female. Among them 20 percent respondents are from the age group below 30 years, 65 percent are from the age group 31-50 years and 15 percent are from the age group 51 above. In terms of education 12.5 percent respondents are illiterate, 12.5 percent have completed +2 levels, 35 percent respondents have completed Bachelor level and 40 percent are from above Bachelor.

All the respondents are categorized into three groups. Among them, 50 percent are the consumers or customers, 25 percent are the producers or seller and 25 percent are media or advertiser. 
Table 2: Meaning of Advertisement

\begin{tabular}{|c|c|c|c|c|c|c|c|c|}
\hline \multirow[t]{3}{*}{ Respondents Types } & \multicolumn{6}{|c|}{ Opinions } & \multirow{3}{*}{ Total } & \multirow{3}{*}{$\%$} \\
\hline & \multicolumn{2}{|c|}{$\begin{array}{l}\text { Promotional } \\
\text { Tools }\end{array}$} & \multicolumn{2}{|c|}{ Information } & \multicolumn{2}{|c|}{$\begin{array}{l}\text { Artistic } \\
\text { Creation }\end{array}$} & & \\
\hline & Freq. & $\%$ & Freq. & $\%$ & Freq. & $\%$ & & \\
\hline Consumer/Customer & 50 & 50 & 50 & 50 & & & 100 & 50 \\
\hline Producer/Seller & 30 & 60 & 10 & 20 & 10 & 20 & 50 & 25 \\
\hline Advertiser/Media & 25 & 50 & 15 & 30 & 10 & 20 & 50 & 25 \\
\hline Total & & & & & & & 200 & 100 \\
\hline
\end{tabular}

Source: Field Survey

The respondents take the advertisement in different ways. Table 2 highlights that 50 percent of Consumer or customers take the advertisement as promotional tools whereas 50 percent of them take it as information about the products. Similarly 60 percent of the respondents (producer/seller) understand the advertisement as promotional tools and 20 percent of them understand it as information and 20 percent of them understand it as artistic creation. The above table shows that 50 percent of advertiser or media take it as promotional tools, 30 percent of them take it as information and 20 percent of them take it as artistic creation.

Table 3: Key Function of Advertisement

\begin{tabular}{|l|l|l|l|l|l|l|l|l|l|}
\hline $\begin{array}{l}\text { Respondents } \\
\text { Types }\end{array}$ & \multicolumn{9}{|l|}{ Opinion } \\
& \multicolumn{2}{|c|}{$\begin{array}{c}\text { Sales } \\
\text { promotion }\end{array}$} & \multicolumn{2}{|l|}{ Value Added } & \multicolumn{2}{|c|}{ Information } & \multicolumn{2}{|c|}{$\begin{array}{c}\text { Not } \\
\text { understand }\end{array}$} & \\
\hline & Freq. & $\%$ & Freq. & $\%$ & Freq. & $\%$ & Freq. & $\%$ & Total \\
\hline $\begin{array}{l}\text { Consumer } \\
\text { Customer }\end{array}$ & 50 & 50 & 10 & 10 & 30 & 30 & 10 & 10 & 100 \\
\hline $\begin{array}{l}\text { Producer } / \\
\text { Seller }\end{array}$ & 20 & 40 & 10 & 20 & 20 & 40 & - & - & 50 \\
\hline $\begin{array}{l}\text { Advertiser/ } \\
\text { Media }\end{array}$ & 20 & 40 & 10 & 20 & 20 & 40 & - & - & 50 \\
\hline Total & 80 & & 40 & & 70 & & 10 & & 200 \\
\hline
\end{tabular}

Source: Field Survey

Table 3 depicts that different respondents have different opinions regarding the key functions of advertisement. As shown by table no. 3, 50 percent of consumers or customers' opinion regarding the key function of advertisement as sales promotion, in the view of 10 percent of them advertisement adds value to the product whereas 30 percent of them, advertisement gives information about the products to the market and 10 percent of them do not understand the 
function of advertisement. According to above table 40 percent of the respondents (producers and seller) understand it as sales promotion activities and 20 percent of them it adds value and 40 percent of them has taken the information as the key function of the advertisement. Likewise, according to 40 percent of advertiser or media viewed sales promotion as the key function of advertisement and 20 percent has taken value added as a key function where as in the view of 40 percent of them an information as a key function .

Table 4: Advertising impact on consumer behavior

\begin{tabular}{|c|c|c|c|c|c|c|c|c|}
\hline \multirow{3}{*}{$\begin{array}{l}\text { Respondents } \\
\text { Types }\end{array}$} & \multicolumn{6}{|c|}{ Opinion } & \multirow{3}{*}{ Total } & \multirow{3}{*}{$\%$} \\
\hline & \multicolumn{2}{|c|}{ Yes } & \multicolumn{2}{|l|}{$\mathrm{No}$} & \multicolumn{2}{|c|}{ Sometimes } & & \\
\hline & Freq. & $\%$ & Freq & $\%$ & Freq & $\%$ & & \\
\hline Consumer/Customer & 30 & 30 & 20 & 20 & 50 & 50 & 100 & 50 \\
\hline Producer/Seller & 20 & 40 & 20 & 40 & 10 & 20 & 50 & 25 \\
\hline Advertiser/Media & 10 & 20 & 20 & 40 & 20 & 40 & 50 & 25 \\
\hline Total & 60 & 30 & 60 & 30 & 80 & 40 & 200 & 100 \\
\hline
\end{tabular}

Source: Field Survey

Table 4 illustrates that 30 percent of consumer or customer is agreed with the impact of advertising on consumer buying behavior and in the view of 50 percent of them sometimes there is an impact of advertising in consumer behavior. 40 percent of producer or seller expressed positively on impact of advertising and 20 percent of them expressed it sometimes customers are influenced by advertisement. According to 20 percent of advertiser or media ,audience are motivated with advertising in purchasing decision and 40 percent of them said sometimes the audience are motivated with advertising.

Table no. 5: Effect of Advertisement

\begin{tabular}{|c|c|c|c|c|c|c|c|c|}
\hline \multirow{3}{*}{ Respondents Types } & \multicolumn{6}{|c|}{ Opinions } & \multirow{3}{*}{ Total } & \multirow{3}{*}{$\%$} \\
\hline & \multicolumn{2}{|l|}{ Yes } & \multicolumn{2}{|l|}{ No } & \multicolumn{2}{|c|}{ Little Bit } & & \\
\hline & Freq. & $\%$ & Freq. & $\%$ & Freq. & $\%$ & & \\
\hline Consumer/Customer & 50 & 50 & 20 & 20 & 30 & 30 & 100 & 50 \\
\hline Producer/Seller & 40 & 80 & - & - & 10 & 20 & 50 & 25 \\
\hline Advertiser/Media & 30 & 60 & 5 & 10 & 15 & 30 & 50 & 25 \\
\hline Total & 120 & 60 & 25 & 12.5 & 55 & 27.5 & 200 & 100 \\
\hline
\end{tabular}

Source: Field Survey

Table 5 indicates that 50 percent of the consumers or customers are agreed with positive effect of advertisement in consumer buying behavior whereas 20 of them are not agreed with this view. Regarding producer or seller, 80 percent of them are agreed with the effect of 
advertisement in consumer behavior and according to 20 percent of them there is a little bit effect of advertisement in consumer behavior. Similarly 60 percent of advertiser or media expressed about positive effect of advertisement in consumer behavior and in the view of 30 percent of them there is a little bit effect of advertisement.

Table no. 6: More Effective Advertising Media

\begin{tabular}{|l|l|l|l|l|l|l|l|l|l|}
\hline \multirow{2}{*}{$\begin{array}{l}\text { Respondents } \\
\text { Types }\end{array}$} & \multicolumn{9}{|l|}{ Opinion } \\
\cline { 2 - 13 } & \multicolumn{2}{|c|}{ TV } & \multicolumn{2}{|c|}{ Radio } & \multicolumn{2}{c|}{ Print } & \multicolumn{2}{c|}{$\begin{array}{c}\text { Hording } \\
\text { Board }\end{array}$} & Total \\
\cline { 2 - 12 } & Freq. & $\%$ & Freq. & $\%$ & Freq. & $\%$ & Freq. & $\%$ & \\
\hline Consumer/Customer & 40 & 40 & 30 & 30 & 10 & 10 & 20 & 20 & 100 \\
\hline Producer/Seller & 25 & 50 & 12 & 24 & 6 & 12 & 7 & 14 & 50 \\
\hline Advertiser/Media & 25 & 50 & 12 & 24 & 7 & 14 & 6 & 12 & 50 \\
\hline Total & 90 & 45 & 54 & 27 & 23 & 11.5 & 33 & 16.5 & 200 \\
\hline & & & & & & & & & \\
\hline
\end{tabular}

Source: Field Survey

Table 6 describes different groups are affected by different advertising media. Table no. 5 shows that 40 percent of consumer or customers are more affected by TV advertisement and in the view of 30 percent of them radio advertisement is more effective and 10 percent said print media is more effective whereas according to 20 percent of the consumers hording board is more effective to convince the customers about the advertised product. 50 percent of the producer or seller expressed TV is more effective media to influence the customers and 24 percent of them is agreed with radio as more effective media for advertisement. According to table no. 5, print media is more effective media for 12 percent of producer or seller. Similarly in the view of 14 percent of them, hording board is more effective media. In the view of 50 percent of advertiser or media, TV is more effective media and rest of 50 percent of the respondents are divided in different media such as radio, print and hording board etc.

\section{Conclusion}

The study has been done to analyze the consumer behavior in purchasing decision and examine the impact of advertisement in buying behavior of consumers. According to the respondents taken for the study there is positive impact of advertising on consumer behavior. Most of the respondents have taken advertising as promotional tools that can convince the customers towards the products and Sales promotion is taken as the key function of advertisement to attract them. According to the respondents, television is more effective media to influence and convince the audience towards the advertised products. The study shows that the customers are highly affected by the advertisement as it creates curiosity on the customers. There is positive impact of advertisement on consumer behavior but according to the respondents most of the people also think about their needs before buying any goods and services. In the conclusion, it can be said that advertisement should design in such a way that can draw the 
attention of the audience, arouse interest towards the advertised product, create desire on the customers and take action towards the product.

\section{References}

Alsmadi, S. (2006). The power of celebrity endorsement in brand choice behavior: An empirical study of consumer attitudes in Jordon. Journal of Accounting Business $\mathcal{E}$ Management, 13.

Ayanwale, A.B., Alimi, T., \& Ayanbimipe, M.A. (2005). The influence of advertising on consumer brand preference. Journal of Social Science, 10(1).

Brosekhan, A. A. \& Velayutham, C.M. (2013). An emprical study on consumers buying behavior towards selected home appliance products in Ramanathapuram. Journal of Business and Management.

Goldsmith , R.E., \& Lafferty, B.A. (2002). Consumer response to websites \& their influence on advertising effectiveness. Journal of Electronic Networking Application and Policy, 12(4).

Haghshenas, L., Abedi, A., Ghorbani,E., Kamali, A. \& Harooni, M. (2013). Review consumer behavior and factors affecting on purchasing decisions. Singaporean Journal of Business Economics and Management Studies, 1(10).

Katke, K. (2007). The impact of television advertising on child health \& family spending. International Marketing Conference on Marketing $\mathcal{E}$ Society.

Louden, D. L., \& DeltaBitta, A. J. (2002). Consumer behavior. New Delhi: Tata McGraw Hill Education Pvt. Ltd.

Latif, A., \& Abideen, Z. U. (2011). Effects of television advertising on children: A Pakistani perspective. European Journal of Economics, Finance and Administrative Sciences, 30.

Mendelson, A. L., \& Bolls, P.D. (2002). Emotional effects of advertising on young adult of lower socio economic status. Retrieved from http:/ / www.allacademic.com/ meta/p mla apa research citatiiion1/1/1/3/7/p1138 index.html.

Priya, P., Baisya, R.K., \& Sharma, S. (2010). Television advertisements and children's buying behavior. Marketing Intelligence and Planning, 28(2), 151-169.

Schiffman, L.G., \& Kanuk, L. (2009). Consumer behavior. New Delhi: Pearson Dorling Kideraley(India) Pvt. Ltd.

Wang, S. L., \& Toncar, (2009). Examining beliefs and attitudes towards online advertising among chinese consumers. An International Journal, 3(1).

Yakup, D., \& Jablonsk, S. (2012). Integrated approach to factors affecting consumers purchase behavior in Poland: An empirical study. Global Journals. 